\title{
Seed Reserves Partition and Light Compensation Point of Mahogany (Swietenia macrophylla King) Seedlings Growth Under Low Photosynthetic Active Radiation
}

\author{
José Pires de Lemos Filho*1 ${ }^{*}$ and Ricardo Jenner Duarte ${ }^{1}$ \\ ${ }^{1}$ Departamento de Botânica, Instituto de Ciências Biológicas, Universidade Federal de Minas Gerais. Caixa Postal \\ 486, 31270-110-Belo Horizonte- Minas Gerais- Brazil.
}

\begin{abstract}
The aim of this study was to verify the dry mass partition of the seed reserves during the initial growth of Swietenia macrophylla_seedlings, in the dark, and at low levels of photosynthetically active radiation: $0.125 ; 3.12$ and 52 $\mu \mathrm{mol} . \mathrm{m}^{-2} . \mathrm{s}^{-1}$. After 50 days, the dry mass of the seed reserves did not differ with treatments, but the total dry mass and leaf area were higher in the seedlings under higher light treatment. No difference in root/shoot ratio was observed between treatments, but the leaf area ratio was lower at higher light. Only the seedlings grown at 52 $\mu \mathrm{mol} . \mathrm{m}^{-2} . \mathrm{s}^{-1}$ showed a positive dry mass increase in relation to the mobilized seed reserves. With the values of the net increase of the seedling mass, a linear equation was adjusted in relation to the light levels, permitting to determine $3.76 \mu \mathrm{mol} . \mathrm{m}^{-2} . \mathrm{s}^{-1}$ as the seedling light compensation point. These results explain the shade tolerance of the S. macrophylla seedlings.
\end{abstract}

Key words: Swietenia macrophylla, dry mass partition, light compensation point, shade adaptation

\section{INTRODUCTION}

The tropical forest regeneration by seeds depends on many factors, particularly light, temperature and humidity. In the rainforest, light conditions have been imputed to play an important role in seed germination (VázquezYanes \& Orozco-Segovia, 1993). The seedling growth and survival were low, until an increase of irradiation (Auguspurger, 1984). After the germination, the seedlings under the forest canopy, often form nurseries, and shows a slower growth rate, and the further growth also depends largely on the light intensity (Lüttge, 1997).

A continuous reduction of incident light on a leaf, reaches a photosynthetic photon flux density, whose $\mathrm{CO}_{2}$ flux equal to zero, and there is no net photosynthesis. This level of light corresponds to the light compensation point for photosynthesis species (about 8 to $16 \mu \mathrm{mol} . \mathrm{m}^{-}$ ${ }^{2} . \mathrm{s}^{-1}$ for $\mathrm{C}_{3}$ and 6 to $14 \mu \mathrm{mol} \cdot \mathrm{m}^{-2} \cdot \mathrm{s}^{-1}$ for $\mathrm{C}_{4}$ plants) (Nobel, 1991). The values of the light compensation point are higher in sun plants, in relation to shade plants, and shows a decrease from the upper to the lower canopy layers (Lüttge, 1997).

The mahogany, Swietenia macrophylla King., a common species of canopy, is found in both, wet and dry forests of the neotropics (Gerhardt \& Fredriksson, 1995). The seeds that are dispersed through wind and frequently escape from herbivory (Janzen, 1988) show hipogeous and cryptocotylar germination (Alvarenga \& Flores, 1988). Mahogany is considered a heliophyte species that can tolerate moderate levels of light and the seedlings can survive under the canopy with lower growth rates (Brieza Junior \& Sá, 1994). Natural regeneration of S. macrophylla frequently occurred in abandoned pastures and secondary forest vegetation in Costa Rica (Gerhardt \& Fredriksson, 1995). Despite this information, there are no available data about the seed reserve partition during the initial seedling establishment, and about the light compensation point for it. In this study the seed reserves decrease was confronted with the

\footnotetext{
* Author for correspondence
} 
seedling growth, in the dark and under low light levels. A linear equation was fitted with these data, permitting the determination of the $S$. macrophylla seedling light compensation point.

\section{MATERIAL AND METHODS}

The Swietenia macrophylla King seeds of five trees at the dispersal stage were collected from the Campus of the Universidade Federal de Minas Gerais and were stored in plastic box in the refrigerator for a month. The germination was carried out in a chamber under continuous light and $26 \pm 2{ }^{\circ} \mathrm{C}$. After the radicle emergency, seedlings grew for 10 days (epicotyl development until the emergence of the leaf primordial), when they were transplanted to a $500 \mathrm{ml}$ plastic tray, full of washed sandvermiculite mix $(1: 1)$. The pots were taken to a growth room maintained at $25 \pm 2{ }^{\circ} \mathrm{C}, 50-60 \%$ relative humidity, photoperiod of 12 hour, and different photosynthetic photon flux density levels, $52 \mu$ mol.m ${ }^{-2} . \mathrm{s}^{-1} ; 3.1 \mu$ mol.m ${ }^{-2} . \mathrm{s}^{-1} ; 0.125$ $\mu \mathrm{mol} . \mathrm{m}^{-2} . \mathrm{s}^{-1}$ supplied through fluorescent lamps (GRO-LUX/Silvania), and in dark. The density was measured with a LI-189 quantun sensor.

The dry mass was evaluated every 10 days after the seedlings were transplanted during 50 days when four randomly chosen seedlings of each treatment were harvested and divided into shoots, leaves and roots and dried in a microwave oven (MARUR \& SODEK, 1995). Before this procedure, a copy of the leaves was made in order to determine the leaf area. With these values, the root/shoot dry mass ratio, and the leaf area ratio (leaf area/dry mass of the seedling) were determined.

The data were submitted to ANOVA and when $F$ test showed a statistic difference between treatments, the means were compared by the Tukey test $(\mathrm{P}<0.05)$. The seedling light compensation point was determined utilizing a linear equation adjusted between the light levels and the net increase of the seedling dry mass.

\section{RESULTS AND DISCUSSION}

At the first harvest, no statistical differences between the treatments were verified in the dry mass of seedlings and seed reserves (Table 1). During the experimental period there was no difference in the dry mass of the cotyledon (main embryo reserve organ) (Fig. 1), but the total dry mass of the seedlings grown at the high light level was statistically higher (Table 1 and Fig. 2). Despite the high photosynthetic rate, the seedlings grown at highest light level showed similar seed reserves mobilization to the others which were grown under lower irradiation and to even those grown in the dark. Considering the relations between the seedling dry mass increase and seed reserves decrease, only the plants grown under $52 \mu \mathrm{mol} \cdot \mathrm{m}^{-2} \cdot \mathrm{s}^{-1}$ of photosynthetically active radiation (PAR), showed a net photosynthetic rate. At this light level, a higher leaf area was also observed (Fig. 3 ), but there was no statistical difference between the treatments in relation to the shoot height, with a mean of $26.2 \pm 2.7 \mathrm{~cm}$.

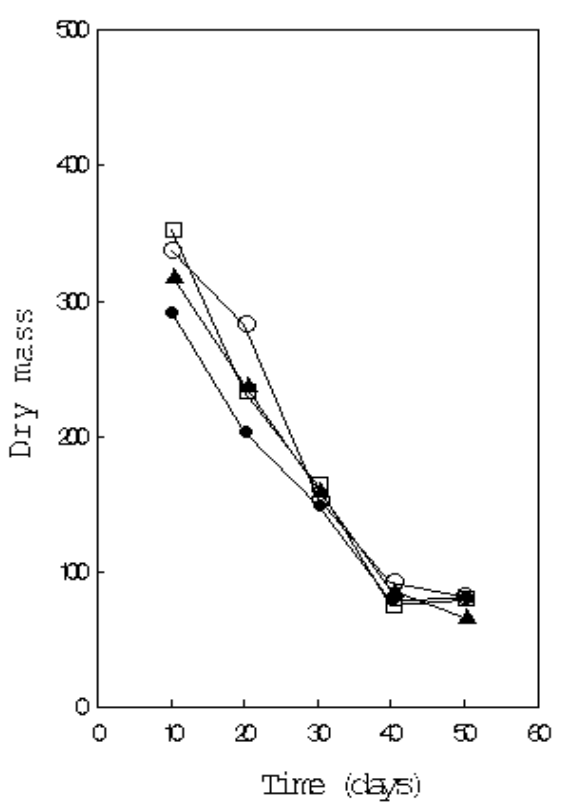

Fig.1. Dry mass (mg) of cotyledons of $S$. Macrophylla seedling grown in different levels of photosynthetically active radiation: dark ( - ), 52 $\mu \mathrm{mol} \cdot \mathrm{m}^{-2} \cdot \mathrm{s}^{-1} \quad 3,1 \mu \mathrm{mol} \cdot \mathrm{m}^{-2} \cdot \mathrm{s}^{-1}(\Delta-\Delta)$, and 0,125 $\mu \mathrm{mol} . \mathrm{m}^{-2} \cdot \mathrm{s}^{-1}(\bullet-\bullet)$ 
Table 1. Dry mass, initial (10 days after the beginning of treatments), final (over 50 days after the beginning of treatments); and its variation in cotyledons and in the seedlings of S. macrophilla, over 50 days of growth at different levels of photosynthetically active radiation.

Dry Mass (mg)

Light Levels

Cotyledons

Seedlings

\begin{tabular}{lcccccc} 
& initial & Final & Variation & Initial & Final & Variation \\
$52 \mu \mathrm{mol} . \mathrm{m}^{-2} \cdot \mathrm{s}^{-1}$ & $337 \mathrm{a}$ & $81 \mathrm{a}$ & 256 & $51,6 \mathrm{a}$ & $791 \mathrm{a}$ & 739 \\
$3,1 \mu \mathrm{mol} \cdot \mathrm{m}^{-2} \cdot \mathrm{s}^{-1}$ & $318 \mathrm{a}$ & $66 \mathrm{a}$ & 252 & $48,1 \mathrm{a}$ & $298 \mathrm{~b}$ & 250 \\
$0,125 \mu \mathrm{mol} \cdot \mathrm{m}^{-2} \cdot \mathrm{s}^{-1}$ & $291 \mathrm{a}$ & $81 \mathrm{a}$ & 210 & $40,8 \mathrm{a}$ & $262 \mathrm{~b}$ & 221 \\
$\quad$ Dark & $352 \mathrm{a}$ & $80 \mathrm{a}$ & 272 & $51,9 \mathrm{a}$ & $234 \mathrm{~b}$ & 182 \\
\hline
\end{tabular}

Means followed by same letter in the same column are no different by the Tuckey test $(\mathrm{p}<0,05)$.

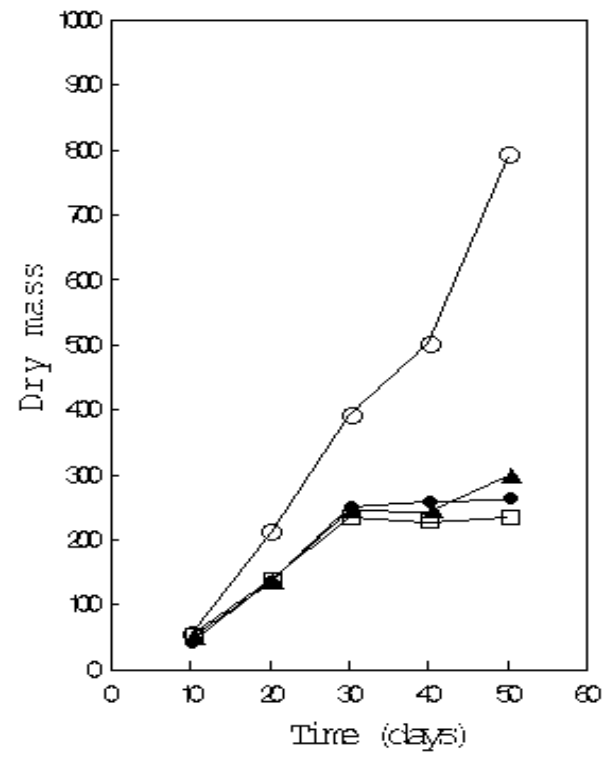

Fig. 2. Dry mass (mg) of S. macrophylla seedling grown in different levels of photosynthetically active radiation: dark ( - ), $52 \mu$ mol. $\mathrm{m}^{-2} \cdot \mathrm{s}^{-1} \quad(\mathrm{o}-\mathrm{O})$, $3,1 \mu \mathrm{mol} \cdot \mathrm{m}^{-2} \cdot \mathrm{s}^{-1}(\Delta-\Delta)$, and $0,125 \mu \mathrm{mol} \cdot \mathrm{m}^{-2} \cdot \mathrm{s}^{-1}(\bullet-\bullet)$.

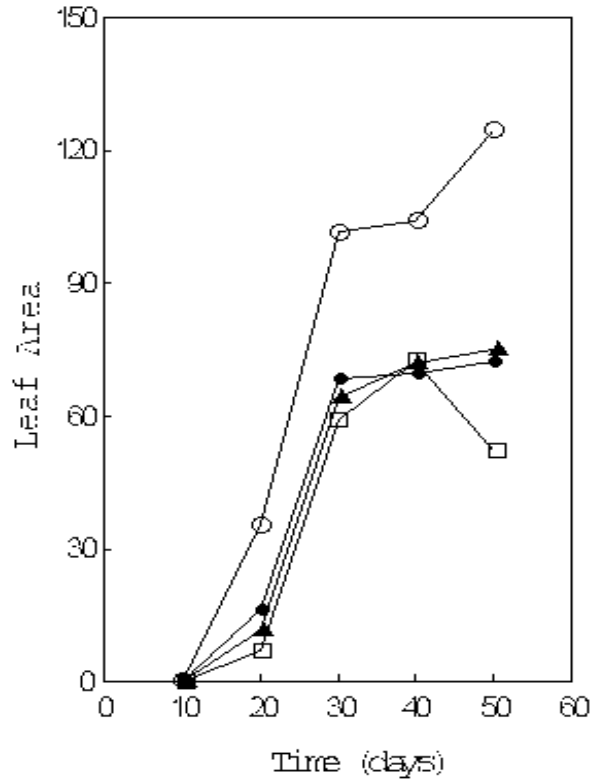

Fig. 3. Leaf area $\left(\mathrm{cm}^{2}\right)$ of $S$. macrophylla seedlings grown under different levels of photosynthetic active radiation: dark ( $-\quad$ ), $52 \mu \mathrm{mol} \cdot \mathrm{m}^{-2} \cdot \mathrm{s}^{-1}(\mathrm{o}-\mathrm{o}), 3,1$ $\mu$ mol. $\mathrm{m}^{-2} \cdot \mathrm{s}^{-1}(\Delta-\Delta)$, and $0,125 \mu \mathrm{mol} \cdot \mathrm{m}^{-2} \cdot \mathrm{s}^{-1}$ 
Table 2. Root/shoot ratio and leaf area ratio of $S$. macrophylla seedlings at 50th day of growth under different light levels.

\begin{tabular}{lcc}
\hline $\begin{array}{c}\text { Light level } \\
\left(\mu \mathrm{mol} \cdot \mathrm{m}^{-2} \cdot \mathrm{s}^{-1}\right)\end{array}$ & $\begin{array}{c}\text { Root/shoot } \\
\text { ratio }\end{array}$ & $\begin{array}{c}\text { Leaf area ratio } \\
\left(\mathrm{cm}^{2} \cdot \mathrm{mg}^{-1}\right)\end{array}$ \\
\hline 52 & $0,16 \mathrm{a}$ & $0,16 \mathrm{~b}$ \\
3,1 & $0,15 \mathrm{a}$ & $0,25 \mathrm{a}$ \\
0,125 & $0,16 \mathrm{a}$ & $0,27 \mathrm{a}$ \\
Dark & $0,15 \mathrm{a}$ & $0,23 \mathrm{ab}$ \\
\hline
\end{tabular}

Means followed by the same letter in the same column are no different by the Tuckey test $(p<0,05)$

With the linear equation adjusted between light levels and net seedling dry mass accumulation $(\mathrm{Y}=-37.77+10.02 \mathrm{X} ; \mathrm{r}=0.9399 ; \mathrm{n}=16)$, the value of $3.76 \mu \mathrm{mol} . \mathrm{m}^{-2} . \mathrm{s}^{-1} \mathrm{PAR}$, was determined as being the seedling ligh compensation point. This values is lower than those out by Nobel (1991) for $\mathrm{C}_{3}$ and $\mathrm{C}_{4}$ specie, and also lower than some Brazilian wood plants such as $16 \mu \mathrm{mol}^{-} \mathrm{m}^{-}$ ${ }^{2} \cdot \mathrm{s}^{-1}$ in leaves of Copaifera langsdorfii (Prado et al, 1994), $59 \mu$ mol. $\mathrm{m}^{-2} \cdot \mathrm{s}^{-1}$ in Stryphnodendroun adstringens (Rocha \& Moraes, 1997). However Reis et al. (1994) in a study with four wood specie showed both higher shade acclimation and lower light compensation point in Colubrina rufa with values between 1 to $5 \mu \mathrm{mol} . \mathrm{m}^{-2} . \mathrm{s}^{-1}$ of PAR in plants grown under higher shade condition. Similar low light compensation point was found in leaves of Agathis mycrostata, a tree of the Australian rain forest (Langenhein et al, 1984).

The low seedling light compensation point of $S$. macropylla grown under low PAR, indicated a high shade tolerance. In a study of photosynthesis under different light and temperature with another meliaceae, Cedrela fissilis, Inoue (1980) concluded that this species was able to adapt to light conditions and showed a umbrophilous character with higher productivity at lower levels of temperature and light intensity. The survival under shade conditions has been related with lower metabolic rates when compared to open environment (Grime, 1979). When studying wood species from wet forests of Amazon and Australia, Langenhein et al. (1984) pointed out that leaves of understory seedlings showed lower light compensation point, higher quantum yeld and lower respiration rates than sum-grown seedlings. The results of the present study confirms the findings of Brieza Junior \& Sá (1994) about the shade tolerance of $S$. macrophylla seedlings, although they had better development in abandoned pasture than in closed forest vegetation as observed by Gerhardt \& Fredriksson (1995). All of these data pointed to a high light acclimation capacity of the mahogany seedlings that allows them to survive under shade and to assume high growth rates when the canopy is open.

\section{RESUMO}

O objetivo deste estudo foi verificar a partição da massa seca das reservas das sementes durante o crescimento de plântulas de Sietenia macrophylla, no escuro e sob baixos níveis de radiação fotossintéticamente ativa: 0,$125 ; 3,12 \mathrm{e}$ $52 \mu \mathrm{mol} . \mathrm{m}^{-2} \cdot \mathrm{s}^{-1}$. Após 50 dias a massa seca das reservas das sementes não diferiram com os diferentes tratamentos de luz. Não foi observado diferenças na razão raíz/parte aérea, mas a razão área foliar foi menor no maior nível de luz. Somente as plântulas crescidas a $52 \mu \mathrm{mol} . \mathrm{m}^{-2} . \mathrm{s}^{-1}$ mostraram um incremento positivo na massa seca em relação às reservas mobilizadas da semente. Uma equação linear foi ajustada entre o incremento líquido de massa seca das plântulas e níveis de luz, permitindo determinar 3,76 $\mu$ mol. $\mathrm{m}^{-2} . \mathrm{s}^{-1}$ como ponto de compensação de luz das plântulas. Esses resultados explicam a tolerância à sombra das plântulas de $S$. macrophylla.

\section{REFERENCES}

Alvarenga, S.; Flores, E. M. (1988), Morfología e germinación de la semilla de caoba, Swietenia macrophylla King (Meliaceae). Revista de Biologia Tropical., 36,. 261-267.

Auguspurger, C. K. (1984), Light requirements of Neotropical tree seedlings: a comparative study of growth and survival. Journal of Ecology, 72, 777-795

Brieza Junior, S.\& Sá, T. D. A. (1994), Sistemas agroflorestais na Amazônia brasileira: espécies arbóreas e atributos desejáveis. In: 
Montoya, L.J. \& Medrado, M.J.S. (eds) I Congresso Brasileiro sobre Sistemas Agroflorestais, 1994, Porto Velho. Anais. Colombo; EMBRAPA-CNPF, pp. 357-373

Gerhardt, K. \& Fredriksson, D. (1995), Biomass allocation by Broad-leaf Mahogany seedlings, Swietenia macrophylla (King), in Abandoned Pasture and Secondary Dry Forest in Guanacaste, Costa Rica. Biotropica, 27, 174182

Grime, J.P. (1979), Plant Strategies and Vegetation Process. John Wiley \& Sons Chichester

Inoue, M.T. (1980), Photosynthesis and transpiration in Cedrela fissilis Vell. seedlings in relation to light intensity and temperature. Turrialba, 30, 280-283

Janzen, D.H. (1988), Management of habitat fragments in a tropical dry forest: growth. Annals of the Missouri Botanical Garden, 75, 105-116

Langenheim, J. H.; Osmond, C. C., Brooks, A. \& Ferrar, P. J. (1984), Photosynthetic responses to light in seedlings of selected Amazonian and Australian rainforest tree species. Oecologia. 63, .215-224

Lüttge, U. (1997), Physiological Ecology of Tropical Plants. Springer-Verlag Berlin

Marcelis, L.F.M (1996), Sink strength as determinant of dry matter partitioning in the whole plant. Journal of Experimental Botany, 47,.1281-1291.
Marur, C. J. \& Sodek, L. (1995), Microwavedrying of plant material for biochemical analysis. Revista Brasileira de Fisiologia Vegetal, 7, 111-114

Nobel, P.S. (1991), Physicochemical and Environmental Plant Physiology. Academic Press, New York

Prado, C. H. B. A.; Moraes, J. A. P. V.\& Matos, E. A. (1994), Gas exchange and leaf water status in potted plants of Copaifera langsdorffii.1. Responses to water stress. Photosynthetica, 30,.207-213

Reis, G. G.; Reis, M. G. F. ;Paula, R. C. ; Maestri, M.\& Borges, E. E. L. (1994), Crescimento e ponto de compensação luminoso em mudas de espécies florestais nativas submetidas a diferentes níveis de sombreamento. Revista Árvore, 18,. 97-105

Rocha, A. M. S.; Moraes, J. A. P. V. (1997), Influência do estresse hídrico sobre as trocas gasosas em plantas jovens envasadas de Stryphnodendron adstringens (Mart.) Coville. Revista Brasileira de Fisiologia Vegetal, 9,.43-48

Vázquez-Yanes, C. \& Orozco-Segovia, A. (1993), Patterns of seed longevity and germination in the tropical rainforest. Annual Review of Ecology and Systematics, 24, 6987 